\title{
Measuring the Sustainability of Cities in Turkey with the Analytic Hierarchy Process
}

\author{
Yağmur Kara \\ International Trade and Finance, Muğla Sıtkı Koçman University, Muğla, Turkey \\ Email: ykara@mu.edu.tr
}

How to cite this paper: Kara, Y. (2019) Measuring the Sustainability of Cities in Turkey with the Analytic Hierarchy Process. Open Journal of Social Sciences, 7, 322-334.

https://doi.org/10.4236/jss.2019.74025

Received: January 15, 2019

Accepted: April 22, 2019

Published: April 25, 2019

Copyright $\odot 2019$ by author(s) and Scientific Research Publishing Inc. This work is licensed under the Creative Commons Attribution International License (CC BY 4.0).

http://creativecommons.org/licenses/by/4.0/

(c) (i) Open Access

\begin{abstract}
The objective of this study is to compare and rank the 81 provinces of Turkey by using the Analytic Hierarchy Process (AHP) in terms of urban sustainability. With this aim, economic, social and environmental sustainability indicators are used. The results indicate that the most sustainable alternative out of 81 is the Eskisehir province. It is followed by Çanakkale, Bursa, İzmir, Bilecik, Giresun, Edirne, Ankara, Rize and Manisa. On the other hand, Diyarbakir, Mardin, Muş, Kars, Bitlis, Yozgat, Sanliurfa, Van, and Batman are less sustainable cities, which are located in the eastern part of the country. Furthermore, the sustainability scores of provinces indicate the development gap between the east and the west of the country.
\end{abstract}

\section{Keywords}

Sustainable Cities, Multi-Criteria Decision Making, Measurement of Sustainability, Urban Sustainability, Analytic Hierarchy Process, Ranking

\section{Introduction}

Turkey has been facing the consequences of rapid population growth and unplanned urbanization like many other developing countries. Between 1950 and 1985 , the population in the cities increased dramatically from $24.8 \%$ to $52.4 \%$. Since 1985, the population living in the urban areas exceeded the rural population. While the average annual urban population growth rate for the country was 2.4\% between 1990 and 2012, the estimated annual urban population growth rate between 2012 and 2030 is $1.6 \%$ [1]. By 2012, the percentage of population living in cities has reached to $72.5 \%$. Not only the increasing population growth but also both domestic and international migration fastened the transformation process from rural to urban areas in the last decades. Due to the geographical position Turkey has been experiencing an intense refugee flow, more than 4 mil- 
lion people, over the past decade. Besides, in 2012 the Law for metropolitan areas had changed in the country. With the Law No. 6360, 13 provinces redefined as metropolitan in addition to the existing metropolitan municipalities and the coverage of urban areas expanded. According to this definitional change statistics of urbanized population increased to $91.35 \%$ by the end of 2013 [2]. Given all these factors, it is urgent to discuss and measure the sustainability of cities in Turkey.

The objective of this study is to measure and rank 81 counties in Turkey as alternatives, according to the urban sustainability framework. To solve this complex problem an Analytical Hierarchy Process (AHP) ratings method was proposed. The indicators combined and weighted according to experts' evaluations in the model. The flexible characteristics of AHP ratings method were provided to compare a large number of alternatives by both qualitative and quantitative indicators. Thus, the model could also be useful in future comparisons.

\section{Methodology and Data}

\subsection{Analytic Hierarchy Process}

The Analytic Hierarchy Process (AHP) developed by Satty to provide a framework for dealing with decision-making problems and complex problems [3]. It is a widely used method by decision makers and researchers for selection or ranking of alternatives in a wide range of problem types [4]. The method is an effective and easy-to-understand tool used in complex problems both with qualitative and quantitative criteria. Combining with other linear programming techniques such as Data Envelopment Analysis, SWOT analysis is another advantage of the method [5].

The basic principles of AHP can be summarized as defining and determining the problem; decomposing the problem in a hierarchy from top through the intermediate levels; constructing a set of pair-wise comparison matrices; testing the consistency index; synthesizing the hierarchy to find out the ranks of the alternatives [6]. AHP makes use of pair-wise comparisons to simplify the judgment process with 1 - 9 ratio scale in Table 1 [7].

In each level of the pairwise comparison matrix, created by assigning the relative weights of the elements using 1 - 9 scale, the elements are compared pairwise with respect to their importance to the element in the higher level. The pairwise comparison matrixes are formed as given in Equation (1). The score of $a_{i j}$ in the pairwise comparison matrix symbolizes the relative importance of the element on the row (i) over the element on column $(j)$.

$$
A=\left[a_{i j}\right]=\left[\begin{array}{cccc}
1 & a_{12} & \ldots & a_{1 n} \\
1 / a_{12} & 1 & \ldots & a_{2 n} \\
\vdots & \vdots & 1 & \vdots \\
1 / a_{1 n} & 1 / a_{2 n} & \ldots & 1
\end{array}\right]
$$

Such that $\left[a_{i j}\right]>0$.

After all pairwise comparisons are completed then the problem turns into 
general process to calculating the largest eigenvalue corresponding to eigenvector to assess the Consistency Index (CI). $A$ is the matrix, $\mathrm{w}$ is the eigenvector and $\lambda_{\max }$ is the largest eigenvalue of the matrix $A$.

$$
\begin{gathered}
A w=\lambda_{\max } w \\
C I=\lambda_{\max }-n / n-1 \\
C R=C I / C R
\end{gathered}
$$

When CI is divided by the Random Consistency Index (RI) the final value must be less than 0.10 [7]. RI provided for different matrix orders in Table 2 [3].

There are two types of comparison in the AHP, relative measurement and absolute measurement. In relative measurement, each alternative is compared with other alternatives. However, in absolute measurement each alternative is compared with one ideal alternative [8]. The absolute measurement method, also called ratings, is convenient in a large number of alternatives and the number of pair wised comparisons is much less than the relative measurement [9]. Another advantage of the absolute measurement is adding or removing alternatives does not affect the old rankings [10]. Also the number of alternatives and criteria does not cause a consistency problem in the ratings model [11].

Table 1. 1 - 9 comparison scale.

\begin{tabular}{cll}
\hline $\begin{array}{c}\text { Intensity of } \\
\text { importance }\end{array}$ & Definition & Explanation \\
\hline 1 & Equal importance & Two activities contribute equally to the objective \\
3 & Moderate importance & Experience and judgment slightly favor one activity over another \\
5 & Strong importance & Experience and judgment strongly favor one activity over another \\
7 & $\begin{array}{l}\text { Very strong or } \\
\text { demonstrated }\end{array}$ & $\begin{array}{l}\text { An activity is favored very strongly over another; its dominance } \\
\text { demonstrated in practice }\end{array}$ \\
& importance & Extreme importance \\
9 & & $\begin{array}{l}\text { The evidence favoring one activity over another is of the highest } \\
\text { possible order of affirmation }\end{array}$ \\
$2,4,6,8$ & & Intermediate values \\
\hline
\end{tabular}

Table 2. Random consistency index (RI).

\begin{tabular}{cccc}
\hline $\mathrm{N}$ & $\mathrm{RI}$ & $\mathrm{N}$ & $\mathrm{RI}$ \\
\hline 1 & 0 & 9 & 1.45 \\
2 & 0 & 10 & 1.49 \\
3 & 0.58 & 11 & 1.51 \\
4 & 0.90 & 12 & 1.53 \\
5 & 1.12 & 13 & 1.56 \\
6 & 1.24 & 14 & 1.57 \\
7 & 1.32 & 15 & 1.59 \\
8 & 1.41 & $\ldots$ & $\ldots$ \\
\hline
\end{tabular}


In absolute measurement, the hierarchy is developed as the same way in relative measurement. The goal of the problem exists at the top and it is followed by criteria and sub criteria hierarchically. The ratings are placed below the sub criterion. Ratings definitions may be qualitative and quantitative. For instance, a sub criterion can be decomposed into qualitative definitions such as hot, cold, low, high, far and near or can be defined quantitatively as certain numerical values or ranges as well. Each sub criterion could have different types and numbers of rating definitions. These definitions vary according to the problem studied. The definitions of the ratings must be carefully created in order to the experiences, the size of the alternatives and the knowledge of the experts to compare intensities. Alternatives do not need to be shown in the hierarchy since alternatives are not compared with each other.

\subsection{Building the Hierarchy}

In order to evaluate urban sustainability of cities a hierarchy three has been created with Super Decisions 2.8 software to apply the AHP ratings method. The hierarchy is presented in Figure 1.

The goal exists at the first level of the hierarchy that is comparing the sustainability of cities in Turkey. Since sustainability is considered with three components economic, environmental and social sustainability are presented at the second level of the hierarchy as criteria. At the third level of the hierarchy, five sub criteria under each criterion are placed.

The indicators under each criterion were determined by a three-stage elimination process. In the first part of the elimination, the literature was searched. The most frequently used indicators were listed among the urban sustainability studies and sustainable development indicator sets of international institutions. Thus, the indicators to represent the sustainability were identified. In the second

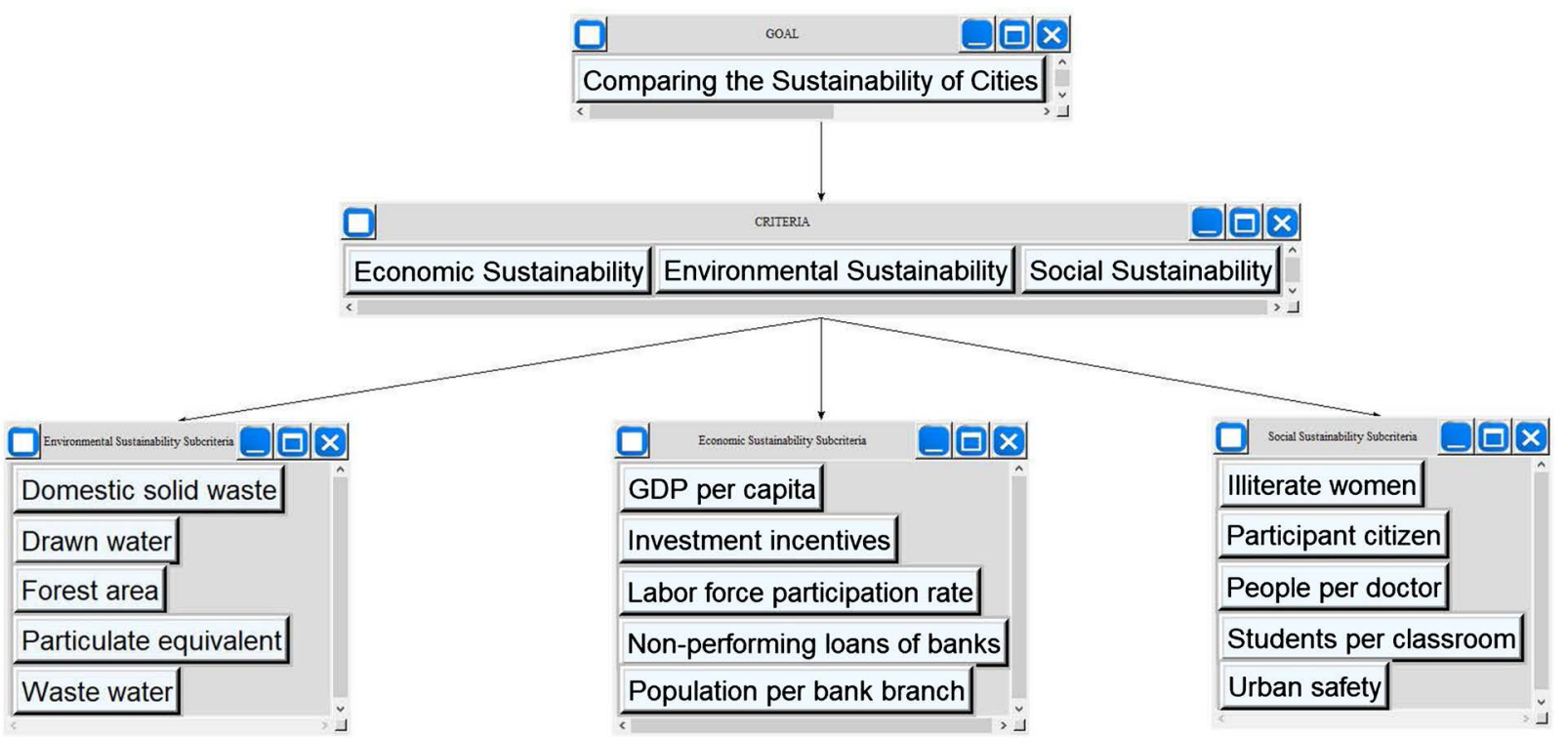

Figure 1. Hierarchy three of the urban sustainability model. 
step, indicators were eliminated by statistical availability, easy to understanding, measurability and reliability principles by the experts. In the third step, the indicators took their final form by taking into consideration the basic principles of the AHP method.

In the AHP method the indicators in the hierarchy should not interact with each other [3]. Another principle is the "magic number 7: plus minus 2" rule. A rational pairwise comparison requires an effective number of criteria [12]. Therefore, five indicators under each component of sustainability were selected and pairwise compared by the experts. Selected sub-criteria were listed in Table 3. In the analysis the period before the lawful definition change of metropolitan cities were taken into consideration.

Labor force participation rate, GDP per capita, investments made with incentive certificates, population per bank branch and non-performing loans of banks were chosen as sub criteria of economic sustainability component. Labor force participation rate statistics, refers to people available for work as a percentage of total population aged 15 to 64 , and were obtained from Turkish Statistical Institution (Turkstat). The latest announced income statistics for the provinces were published by Turkstat in 2001. In the following years, income statistics were published only at regional and national level. Therefore, GDP per capita statistics were calculated according to the latest available data. To do so, first the share of national level of GDP for each province was calculated according to the last statistics on the provincial basis. Then the data at the regional level were demoted to the provincial level. In the last stage, per capita values were calculated. The

Table 3. Indicator list.

\begin{tabular}{|c|c|c|c|}
\hline & Indicator & Unit & Years \\
\hline \multirow{5}{*}{$\begin{array}{c}\text { Economic } \\
\text { Sustainability }\end{array}$} & Labor force participation rate & $\%$ & 2008-2009-2010 \\
\hline & GDP per capita & Per capita/\$ & 2008-2009-2010 \\
\hline & Investments with incentive certificate & Per capita/TL & 2008-2009-2010 \\
\hline & Population per bank branch & Person & 2008-2009-2010 \\
\hline & Non-performing loans of banks & Per capita/TL & 2008-2009-2010 \\
\hline \multirow{5}{*}{$\begin{array}{c}\text { Environmental } \\
\text { Sustainability }\end{array}$} & Particulate equivalent & $\mu g / \mathrm{m}^{3}$ & 2008-2009-2010 \\
\hline & Wastes & Per capita-kg & $2008-2010$ \\
\hline & Water abstraction per capita & $1000 \mathrm{~m}^{3} /$ person & $2008-2010$ \\
\hline & Wastewater per capita & $1000 \mathrm{~m}^{3} /$ person & $2008-2010$ \\
\hline & Forest area & $\%$ & 2010 \\
\hline \multirow{5}{*}{$\begin{array}{c}\text { Social } \\
\text { Sustainability }\end{array}$} & Urban safety & $100,000 /$ person & 2008-2009-2010 \\
\hline & Citizen participation & $\%$ & 2007-2009-2010 \\
\hline & Medical doctors per person & Person & $2008-2009-2010$ \\
\hline & Number of students per classroom & Person & 2008-2009-2010 \\
\hline & Illiterate women & $\%$ & 2008-2009-2010 \\
\hline
\end{tabular}


investment incentive certificates data were obtained from the Ministry of Economy to represent the investment capacity of the urban areas. Population per bank branch and non-performing loans of banks statistics, which represent the financial potential of the cities, were taken from Banking Regulation and Supervision Agency.

Air pollution, wastes, forests and water represent main themes of the environmental sustainability. Five indicators selected by the experts which are particulate equivalent, wastes, abstracted water, wastewater and forest area. Wastes, abstracted water, wastewater date are published by TURKSTAT every two years. Forest reserves data were obtained from General Directorate of Forestry. Particle equivalent indicator to represent the air pollution was computed by employing $\mathrm{PM}_{10}$ and $\mathrm{SO}_{2}$ data according to the particle equivalent formula (PE).

$$
P E=P M_{10}+\left(0.54 * \mathrm{SO}_{2}\right)
$$

Urban safety, citizen participation, medical doctors per person, number of students per classroom and percentage of illiterate women were chosen as five sub-criteria of social sustainability component. Indicators represent the safety and security, social inclusion, health and education topics. The urban safety sub-criteria calculated as the sum of traffic accidents occurred within a year in a province, those affected by these accidents (the number of dead and wounded) and the number of convicts entering the prison according to the crime per 100,000 people.

\subsection{Selection of Experts}

Since there is no general rule about the selection of experts, there are various studies implemented with different numbers of experts in the literature. Gómez-Navarro et al. [13] worked with 5 experts from the public and private sector in their study. Saaty [9] determined the weights of the indicators with 6 experts. Köne and Büke [14] studied with twenty-five experts. Ramanathan and Ganesh [15] made interviews with different interdisciplinary groups. Oddershede, Arias and Cancino [16] applied the pairwise comparison questionnaires to 50 experts. In AHP studies, the knowledge level of the consulted experts' is more important than the number of experts. Besides, there should be a diversity of their study field [17].

In this study, the interviews of environmental sustainability dimension were made with environmental engineers. Selected experts are specialized on environmental sustainability and working in municipalities and private sector. For social and economic sustainability dimensions of the study, academicians were chosen who study specifically on social and economic sustainability topics. It was studied with five experts for each component, fifteen experts in total. Face-to-face interviews made with experts and paired comparison matrices generated for each criteria and sub criteria.

\subsection{Ratings}

In order to make the definition of the ratings, the statistical series of each indi- 
cator were sorted from the lowest to the highest. Then they were divided into three groups such as low, medium and high. After making the rating definitions for each indicator, the standard deviations of the series of the indicators were calculated. The alternatives, which are at the boundaries, have been moved to an upper or lower group according to the direction of the indicators whether the contribution of the indicator to sustainability is negative or positive. Since the weights of the rating definitions for each indicator are different, the experts have also compared the rating definitions. These weights were calculated by the geometric mean method and the inconsistency rates were also checked. All calculations are below the critical value 0.10 .

\subsection{Calculation of Weights}

Aczel and Saaty [18] recommended the geometric mean method to evaluate the expert's pairwise comparisons together. When number of judges is not large enough then the geometric mean can be obtained [19]. Additionally, the most widely used method in the literature is the geometric meaning method [20]. Thus, the weights are calculated by geometric mean method in this study. The weights calculated from pairwise comparisons of experts for criteria or in other words, components of sustainability are given in Table 4. According to the results, experts weighted the environmental sustainability by $44.3 \%$ as the most important component to ensure urban sustainability. Social and economic sustainability components are weighted $38.8 \%$ and $16.9 \%$ respectively. These results reveal the environmental concerns for urban sustainability on the ecological perspective.

The calculated weights of the urban sustainability sub criteria are given in $\mathrm{Ta}$ ble 5 . The weights reflect the substance that the experts give to each criterion for urban sustainability. GDP per capita is the highest weighted factor of the economic sustainability component. It is followed by investments with incentive certificate, labor force participation rate, non-performing loans of banks and, population per bank branch. The weights given to water abstraction per capita and wastewater per capita are the most important factors weighted $40.83 \%$ and $28.36 \%$ respectively, to consider urban environmental sustainability. Particulate equivalent, wastes and forest area are weighted comparatively least important. According to the weights calculated for the social sustainability urban safety indicator acquired the highest weight. It is followed by medical doctors per person, citizen participation, the number of students per classroom and percentage of illiterate women, respectively.

Table 4. The weights derived for sustainability components.

\begin{tabular}{cc}
\hline Criteria & Weight (\%) \\
\hline Economic Sustainability & 16.9 \\
Environmental Sustainability & 44.3 \\
Social Sustainability & 38.8 \\
\hline
\end{tabular}


Table 5. The weights of the sub-criteria.

\begin{tabular}{lcc}
\hline & Indicators & Weights (\%) \\
\hline Labor force participation rate & 11.09 \\
GDP per capita & 47.94 \\
Economic Sustainability & Investments with incentive certificate & 29.26 \\
& Population per bank branch & 4.51 \\
Non-performing loans of banks & 7.20 \\
Total & 100.00 \\
Particulate equivalent & 23.73 \\
Wastes & 9.80 \\
Water abstraction per capita & 40.83 \\
Wastewater per capita & 28.36 \\
Forest area & 7.36 \\
Total & 100.00 \\
Urban safety & 41.28 \\
Citizen participation & 15.49 \\
Medical doctors per person & 22.33 \\
Number of students per classroom & 11.26 \\
Illiterate women & 9.64 \\
Tustainability & 100.00 \\
& &
\end{tabular}

\section{Results}

According to the results obtained from the analysis, provinces ranked from the highest score to the lowest score. The sustainability scores of the provinces presented in Table 6 and Table 7. The "normal" column presents the sustainability results of alternatives. The "idealized values" column was derived from the normals column. These values were obtained by dividing the value of each alternative in the normals column by the highest value in the normals column. Therefore, in the idealized column of values, the best alternative with the highest score has a value of " 1 ". The "raws" result column was obtained directly from the supermatrix. In the hierarchical models, the column of raws and the column of normals are the same.

The results reflect the sustainability of cities relatively to others. According to the results, Eskisehir is the best performer. The city is located in the Eastern Marmara region, close to the two largest metropolitans, Ankara and Istanbul. Approximately $1 \%$ of the country's population resides in Eskişehir. The city's population density is 62 people per $\mathrm{km}^{2}$, below the average density of Turkey, 105 people per $\mathrm{km}^{2}$. Eskişehir provides significant advantages in education, health, transportation and social life opportunities. Eskişehir is followed by Çanakkale, Bursa, İzmir, Bilecik, Giresun, Edirne, Ankara, Rize and Manisa.

Locations of the most sustainable cities and least sustainable cities were visually 
Table 6. Urban sustainability scores of the cities.

\begin{tabular}{|c|c|c|c|c|}
\hline Rank & City & Ideals & Normals & Raws \\
\hline 1 & Eskişehir & 1.000000 & 0.020324 & 0.020324 \\
\hline 2 & Çanakkale & 0.987954 & 0.020079 & 0.020079 \\
\hline 3 & Bursa & 0.919630 & 0.018690 & 0.018690 \\
\hline 4 & İzmir & 0.898893 & 0.018269 & 0.018269 \\
\hline 5 & Bilecik & 0.874712 & 0.017777 & 0.017777 \\
\hline 6 & Giresun & 0.865786 & 0.017596 & 0.017596 \\
\hline 7 & Edirne & 0.859861 & 0.017475 & 0.017475 \\
\hline 8 & Ankara & 0.843728 & 0.017148 & 0.017148 \\
\hline 9 & Rize & 0.824917 & 0.016765 & 0.016765 \\
\hline 10 & Manisa & 0.804385 & 0.016348 & 0.016348 \\
\hline 11 & Bolu & 0.803329 & 0.016327 & 0.016327 \\
\hline 12 & İstanbul & 0.799275 & 0.016244 & 0.016244 \\
\hline 13 & Karabük & 0.798937 & 0.016237 & 0.016237 \\
\hline 14 & Denizli & 0.765526 & 0.015558 & 0.015558 \\
\hline 15 & Aksaray & 0.747465 & 0.015191 & 0.015191 \\
\hline 16 & Konya & 0.740946 & 0.015059 & 0.015059 \\
\hline 17 & Kırklareli & 0.735901 & 0.014956 & 0.014956 \\
\hline 18 & Kayseri & 0.729088 & 0.014818 & 0.014818 \\
\hline 19 & Kilis & 0.725996 & 0.014755 & 0.014755 \\
\hline 20 & Sinop & 0.721760 & 0.014669 & 0.014669 \\
\hline 21 & Kocaeli & 0.716379 & 0.014559 & 0.014559 \\
\hline 22 & Artvin & 0.715870 & 0.014549 & 0.014549 \\
\hline 23 & Antalya & 0.711699 & 0.014464 & 0.014464 \\
\hline 24 & Burdur & 0.706362 & 0.014356 & 0.014356 \\
\hline 25 & Amasya & 0.698066 & 0.014187 & 0.014187 \\
\hline 26 & Adana & 0.691105 & 0.014046 & 0.014046 \\
\hline 27 & Tekirdağ & 0.681174 & 0.013844 & 0.013844 \\
\hline 28 & Gümüşhane & 0.667876 & 0.013574 & 0.013574 \\
\hline 29 & Düzce & 0.664598 & 0.013507 & 0.013507 \\
\hline 30 & Trabzon & 0.662479 & 0.013464 & 0.013464 \\
\hline 31 & Çankırı & 0.662315 & 0.013461 & 0.013461 \\
\hline 32 & Osmaniye & 0.658900 & 0.013391 & 0.013391 \\
\hline 33 & Samsun & 0.655923 & 0.013331 & 0.013331 \\
\hline 34 & Elazığ & 0.653740 & 0.013286 & 0.013286 \\
\hline 35 & Ordu & 0.650002 & 0.013210 & 0.013210 \\
\hline 36 & Hatay & 0.647581 & 0.013161 & 0.013161 \\
\hline 37 & Aydın & 0.643296 & 0.013074 & 0.013074 \\
\hline 38 & Zonguldak & 0.626800 & 0.012739 & 0.012739 \\
\hline 39 & Muğla & 0.623597 & 0.012674 & 0.012674 \\
\hline 40 & Kurşehir & 0.622489 & 0.012651 & 0.012651 \\
\hline 41 & Kastamonu & 0.614684 & 0.012493 & 0.012493 \\
\hline
\end{tabular}


Table 7. Urban sustainability scores of the cities-2.

\begin{tabular}{|c|c|c|c|c|}
\hline Rank & City & Ideals & Normals & Raws \\
\hline 42 & Yalova & 0.613558 & 0.012470 & 0.012470 \\
\hline 43 & Karaman & 0.607752 & 0.012352 & 0.012352 \\
\hline 44 & Uşak & 0.607464 & 0.012346 & 0.012346 \\
\hline 45 & Isparta & 0.591531 & 0.012022 & 0.012022 \\
\hline 46 & Balıkesir & 0.590949 & 0.012010 & 0.012010 \\
\hline 47 & Kırıkkale & 0.587035 & 0.011931 & 0.011931 \\
\hline 48 & Çorum & 0.584635 & 0.011882 & 0.011882 \\
\hline 49 & Tunceli & 0.576544 & 0.011717 & 0.011717 \\
\hline 50 & Nevşehir & 0.570608 & 0.011597 & 0.011597 \\
\hline 51 & Bartın & 0.563681 & 0.011456 & 0.011456 \\
\hline 52 & Bayburt & 0.562394 & 0.011430 & 0.011430 \\
\hline 53 & Sakarya & 0.550961 & 0.011197 & 0.011197 \\
\hline 54 & Kahramanmaraş & 0.544341 & 0.011063 & 0.011063 \\
\hline 55 & Ağrı & 0.544121 & 0.011058 & 0.011058 \\
\hline 56 & Siirt & 0.539880 & 0.010972 & 0.010972 \\
\hline 57 & Adiyaman & 0.539006 & 0.010955 & 0.010955 \\
\hline 58 & Kütahya & 0.531628 & 0.010805 & 0.010805 \\
\hline 59 & Hakkâri & 0.523749 & 0.010644 & 0.010644 \\
\hline 60 & Şırnak & 0.523749 & 0.010644 & 0.010644 \\
\hline 61 & Afyonkarahisar & 0.508707 & 0.010339 & 0.010339 \\
\hline 62 & Erzincan & 0.504877 & 0.010261 & 0.010261 \\
\hline 63 & Malatya & 0.503646 & 0.010236 & 0.010236 \\
\hline 64 & Tokat & 0.498601 & 0.010133 & 0.010133 \\
\hline 65 & Mersin & 0.493603 & 0.010032 & 0.010032 \\
\hline 66 & Niğde & 0.489360 & 0.009946 & 0.009946 \\
\hline 67 & Iğdır & 0.462565 & 0.009401 & 0.009401 \\
\hline 68 & Bingöl & 0.448661 & 0.009118 & 0.009118 \\
\hline 69 & Ardahan & 0.411794 & 0.008369 & 0.008369 \\
\hline 70 & Erzurum & 0.406941 & 0.008270 & 0.008270 \\
\hline 71 & Sivas & 0.397105 & 0.008071 & 0.008071 \\
\hline 72 & Diyarbakır & 0.358408 & 0.007284 & 0.007284 \\
\hline 73 & Gaziantep & 0.344927 & 0.007010 & 0.007010 \\
\hline 74 & Mardin & 0.336233 & 0.006833 & 0.006833 \\
\hline 75 & Muş & 0.336233 & 0.006833 & 0.006833 \\
\hline 76 & Kars & 0.321782 & 0.006540 & 0.006540 \\
\hline 77 & Bitlis & 0.278962 & 0.005670 & 0.005670 \\
\hline 78 & Yozgat & 0.276388 & 0.005617 & 0.005617 \\
\hline 79 & Şanlıurfa & 0.256549 & 0.005214 & 0.005214 \\
\hline 80 & Van & 0.196562 & 0.003995 & 0.003995 \\
\hline 81 & Batman & 0.195417 & 0.003972 & 0.003972 \\
\hline
\end{tabular}


represented in Figure 2. The top ten provinces that received the highest sustainability scores were shown in the black circle and the provinces with the lowest scores were shown in the red circle. The map illustrates the geographical distribution of sustainability scores. Diyarbakir, Mardin, Muş, Kars, Bitlis, Yozgat, Sanliurfa, Van, and Batman are less sustainable cities that are located in the eastern part of the country. The provinces with high sustainability scores are mostly located in the western provinces.

\section{Conclusions}

Increasing urbanization has led to urban sustainability discussions since the country has been experiencing rapid population growth and migration. As a result of the process creating sustainable cities became a challenge. In this context, it is essential to measure the sustainability of urban areas.

Achieving urban sustainability requires monitoring the past and current performances of the cities. Thus, policymakers can evaluate the effects of their policies and monitor the progress towards sustainability. Moreover the strategies can be developed or changed according to the needs of society.

This study provides a new measurement approach to compare the urban sustainability by means of AHP ratings method based on the judgements of the experts. The urban sustainability of Turkish provinces was ranked through AHP ratings method since the method allows comparing a large number of the alternatives. Fifteen criteria were employed which have been grouped in three clusters related to economic, environmental and social sustainability. The results of the analysis have shown that provinces namely Eskişehir, Çanakkale, Bursa, İzmir, Bilecik, Giresun, Edirne, Ankara, Rize and Manisa have been considered more sustainable. On the other hand, Diyarbakir, Mardin, Muş, Kars, Bitlis, Yozgat, Sanliurfa, Van, and Batman have considered least sustainable provinces.

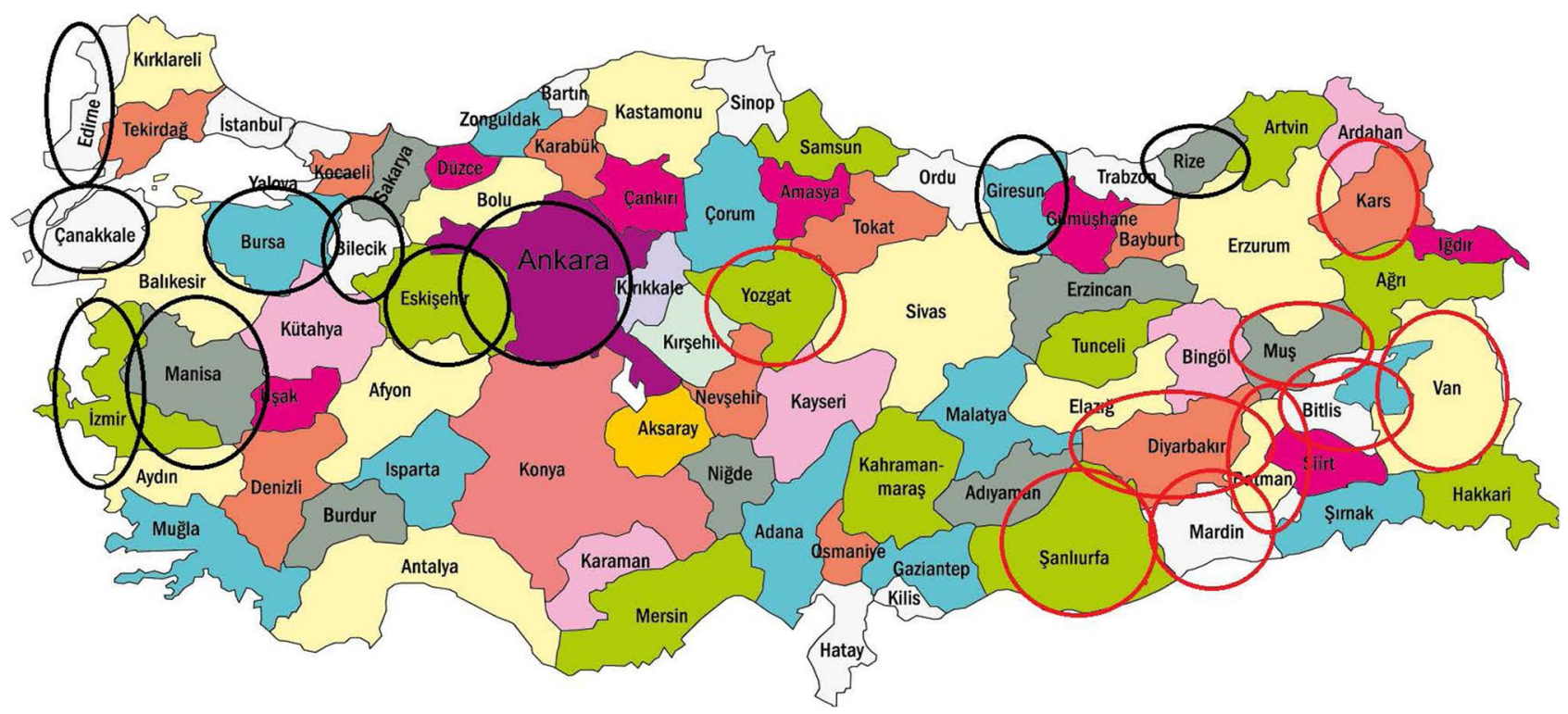

Figure 2. Urban sustainability comparison of the provinces. 
From the point of regional development disparity, the Western provinces have higher sustainability rates compared to the Eastern provinces.

In terms of sustainability components, the study reveals another conclusion. The weights given by the experts to the indicators can help the decision makers to reconsider urban sustainability. The results have shown that environment is the main concern compared to social and economic pillars of sustainability. Water and wastewater management are considered as the most important factor to ensure environmental sustainability. In terms of economic sustainability, the weights given to the indicators reveal that the income level and investment potential of the cities are the most important indicators. Urban security and health are essential indicators to achieve social sustainability in urban areas.

As a result of this paper various policies are simply proposed below:

- The model can be applied to different countries by modification of indicators and/or expert evaluations can be repeated. Consequently, the model can provide a measurement tool to support decision makers. Periodically calculated measurements can help to determine progress or performance losses.

- Divergent models can be developed for each component of sustainability. Thus, economic, environmental and social sustainability performances can be evaluated specifically.

- The steps to be taken by both central and local governments could contribute to the urban sustainability as a whole.

- Sustainability awareness should be created for urban residents. Thus residents could capitalize to governmental sustainability projects and municipalities' decisions.

\section{Conflicts of Interest}

The author declares no conflicts of interest regarding the publication of this paper.

\section{References}

[1] United Nations Population Division (2018) World Urbanization Prospects: 2018 Rev.

https://population.un.org/wup/default.aspx?aspxerrorpath=/wup/Publications/Files /WUP2018-KeyFacts.pdf

[2] TURKSTAT (2018) The Results of Address Based Population Registration System. http://www.turkstat.gov.tr/PreHaberBultenleri.do?id=27587

[3] Saaty, T.L. (1980) The Analytic Hierarchy Process, Planning, Priority Setting, and Resource Allocation. McGraw-Hill, NewYork.

[4] Russo, R.D.F.S.M. and Camanho, R. (2015) Criteria in AHP: A Systematic Review of Literature. Procedia Computer Science, 55, 1123-1132. https://doi.org/10.1016/j.procs.2015.07.081

[5] Ho, W. (2008) Integrated Analytic Hierarchy Process and Its Applications: A Literature Review. European Journal of Operational Research, 186, 211-228.

https://doi.org/10.1016/j.ejor.2007.01.004

[6] Saaty, T.L. (1985) Analytical Planning the Organization of Systems. Pergamon 
Press, New York.

[7] Saaty, T.L. (2000) Fundamentals of Decision Making and Priority Theory with Analytic Hierarchy Process. RWS Publications, Pittsburgh.

[8] Saaty, T.L. (2006) Rank from Comparisons and from Ratings in the Analytic Hierarchy Network Processes. European Journal of Operational Research, 168, 557-570. https://doi.org/10.1016/j.ejor.2004.04.032

[9] Saaty, T.L. (1986) Absolute and Relative Measurement with the AHP. The Most Livable Cities in the United States. Socio-Economic Planning Sciences, 20, 327-331. https://doi.org/10.1016/0038-0121(86)90043-1

[10] Silva, A.C.S., Belderrain, M.C.N. and Pantoja, F.C.M. (2010) Prioritization of R\&D Projects in the Aerospace Sector: AHP Method with Ratings. Journal of Aerospace Technology and Management, 2, 339-348. https://doi.org/10.5028/jatm.2010.02039110

[11] Ohnishi, S.I., Saito, T., Yamanoi, T. and Imai, H. (2011) A Weights Representation for Absolute Measurement AHP Using Fuzzy Sets Theory. 5th International Symposium on Computational Intelligence and Intelligent Informatics, Floriana, 15-17 September 2011, 67-70. https://doi.org/10.1109/ISCIII.2011.6069744

[12] Saaty, T.L. and Özdemir, M.S. (2003) Why the Magic Number Seven Plus or Minus Two. Mathematical and Computer Modelling, 38, 233-244. https://doi.org/10.1016/S0895-7177(03)90083-5

[13] Gómez-Navarro, T., García-Melón, M., Acuña-Dutra, S. and Díaz-Martín, D. (2009) An Environmental Pressure Index Proposal for Urban Development Planning Based on the Analytic Network Process. Environmental Impact Assessment Review, 29, 319-329. https://doi.org/10.1016/j.eiar.2008.10.004

[14] Köne, A.Ç. and Büke, T. (2017) Eco-Efficiency Analysis Using Analytic Hierarchy Process Approach. International Journal of the Analytic Hierarchy Process, 9, 167-182. https://doi.org/10.13033/ijahp.v9i2.477

[15] Ramanathan, R. and Ganesh, L.S. (1995) Energy Resource Allocation Incorporating Qualitative and Quantitative Criteria: An Integrated Model Using Goal Programming AHP. Socio-Economic Planning Sciences, 29, 197-218. https://doi.org/10.1016/0038-0121(95)00013-C

[16] Oddershede, A., Arias, A. and Cancino, H. (2007) Rural Development Decision Support Using the Analytic Hierarchy Process. Mathematical and Computer Modelling, 46, 1107-1114. https://doi.org/10.1016/j.mcm.2007.03.006

[17] Ramanathan, R. (2001) A Note on the Use of the Analytic Hierarchy Process for Environmental Impact Assessment. Journal of Environmental Management, 63, 27-35. https://doi.org/10.1006/jema.2001.0455

[18] Aczel, J. and Saaty, T. (1983) Procedures for Synthesizing Ratio Judgements. Journal of Mathematical Psychology, 27, 93-102. https://doi.org/10.1016/0022-2496(83)90028-7

[19] Wu, W.H., Chiang, C.T. and Lin, C.T. (2008) Comparing the Aggregation Methods in the Analytic Hierarchy Process When Uniform Distribution. WSEAS Transactions on Business and Economics, 5, 82-87.

[20] Melón, M.G., Beltran, P.A. and Cruz, M.C.G. (2008) An AHP-Based Evaluation Procedure for Innovative Educational Projects: A Face-to-Face Vs. Computer-Mediated Case Study. Omega, 36, 754-765. https://doi.org/10.1016/j.omega.2006.01.005 